\title{
Contextualising biblical exegesis: What is the African biblical hermeneutic approach?
}

\begin{tabular}{|c|c|}
\hline \multicolumn{2}{|c|}{$\begin{array}{l}\text { Author: } \\
\text { Mbengu D. Nyiawung }{ }^{1,2}\end{array}$} \\
\hline $\begin{array}{l}\text { Affiliations: } \\
{ }^{1} \text { Department } 0 \\
\text { Testament, Pre } \\
\text { Theological Se } \\
\text { Cameroon }\end{array}$ & $\begin{array}{l}\text { of New } \\
\text { esbyterian } \\
\text { eminary, }\end{array}$ \\
\hline $\begin{array}{l}{ }^{2} \text { Department o } \\
\text { Testament Stu } \\
\text { University of } \mathrm{P} \\
\text { South Africa }\end{array}$ & $\begin{array}{l}\text { of New } \\
\text { dies, } \\
\text { retoria, }\end{array}$ \\
\hline $\begin{array}{l}\text { Note: } \\
\text { Rev. Dr Mbeng } \\
\text { is a research fel } \\
\text { Ernest van Eck, } \\
\text { of New Testam } \\
\text { Faculty of Theo } \\
\text { of Pretoria, Pre } \\
\text { Africa. This arti } \\
\text { extensive rewo } \\
\text { article publishe } \\
\text { accredited Jour } \\
\text { Presbyterian Th } \\
\text { Seminary Kumb } \\
\text { Kumba, 2013, } \\
\text { 144-168. }\end{array}$ & $\begin{array}{l}\text { D. Nyiawung } \\
\text { low of Prof. } \\
\text { Department } \\
\text { ent Studies, } \\
\text { logy, University } \\
\text { toria, South } \\
\text { icle is an } \\
\text { rking of an } \\
\text { ed in the non- } \\
\text { rnal of the } \\
\text { heological } \\
\text { ba, Voices from } \\
\text { Volume } 4,\end{array}$ \\
\hline $\begin{array}{l}\text { Corresponden } \\
\text { Mbengu Nyiau }\end{array}$ & $\begin{array}{l}\text { ice to: } \\
\text { Nung }\end{array}$ \\
\hline $\begin{array}{l}\text { Email: } \\
\text { revmbengu@y }\end{array}$ & yahoo.com \\
\hline $\begin{array}{l}\text { Postal address } \\
\text { PO Box 590, K } \\
\text { West Region, }\end{array}$ & $\begin{array}{l}\text { umba, South } \\
\text { Cameroon }\end{array}$ \\
\hline $\begin{array}{l}\text { Dates: } \\
\text { Received: } 24 \mathrm{~N} \\
\text { Accepted: } 28 \mathrm{~J} \\
\text { Published: } 28\end{array}$ & $\begin{array}{l}\text { May } 2013 \\
\text { uly } 2013 \\
\text { Oct. } 2013\end{array}$ \\
\hline $\begin{array}{l}\text { How to cite th } \\
\text { Nyiawung, M. } \\
\text { 'Contextualisin } \\
\text { exegesis: What } \\
\text { African biblical } \\
\text { approach?', H7 } \\
\text { Studies/Theolo } \\
69(1), \text { Art. \#20 } \\
\text { http://dx.doi.o } \\
\text { hts.v69i1.2011 }\end{array}$ & $\begin{array}{l}\text { is article: } \\
\text { D., 2013, } \\
\text { tg biblical } \\
\text { t is the } \\
\text { I hermeneutic } \\
\text { TS Teologiese } \\
\text { gical Studies } \\
11,9 \text { pages. } \\
\text { rg/10.4102/ }\end{array}$ \\
\hline $\begin{array}{l}\text { Copyright: } \\
\text { (C) 2013. The A } \\
\text { Licensee: AOSI } \\
\text { OpenJournals. } \\
\text { is licensed und } \\
\text { Creative Comn } \\
\text { Attribution Lic }\end{array}$ & $\begin{array}{l}\text { IS } \\
\text { This work } \\
\text { der the } \\
\text { nons } \\
\text { ense. }\end{array}$ \\
\hline $\begin{array}{l}\text { Read online: } \\
\text { 口isin: }\end{array}$ & $\begin{array}{l}\text { Scan this QR } \\
\text { code with your } \\
\text { smart phone or } \\
\text { mobile device } \\
\text { to read online. }\end{array}$ \\
\hline
\end{tabular}

This article responded to the question about the right methodology needed for the reconstruction of a viable African Christian theology. It equally contributed an answer to earlier concerns by Appiah-Kubi, Stinton and Nyiawung, who had grappled with an African response to the question of Jesus' identity: 'Who do you say I am?' (Lk 9:20). It also attended to Aben's remark that Africans contribute minimally to biblical theology especially in the domain of biblical exegesis. Finally, it proposed an African biblical hermeneutic approach, a shift of paradigm from the text, its author as well as its context to the context of the subject of exegesis as a contextual approach of biblical criticism. Three main conclusions emerged from the article, namely, (1) the African context contains enormous potentials that can enhance the understanding and interpretation of biblical texts; (2) from the perspective of biblical interpretation, there is no superior context or culture; and (3) the African biblical hermeneutic approach is a possible route to the development of an authentic African Christian theology.

\section{Introduction}

In agreement with Bediako (2000:3) that Christianity is a universal religion, this article introduces an approach in biblical criticism, which takes the African worldview into consideration. As a hermeneutical and contextual approach, it emphasises a move from what the text meant to its original audience to what it means to Africans in their context. In fact, contextual issues are an obligation on exegesis today. From a hermeneutic perspective, the proposed approach is a blend between the historical data of the text, its sociological concerns and the contextual realities of the subject of exegesis. It may seem erroneous to characterise the reformation in the area of biblical interpretation towards the end of the 20th century as a sort of crisis (cf. Rowland \& Corner 1989:38). Such refurbishment should rather be celebrated as an urge to interpret God's mind as contained in Scripture to humans in a way that people may feel God's effective presence in their midst (Jn 1:14). The urgency of the present methodology is compelled by the awareness that Scripture speaks to people differently, depending on their context.

Descriptive in form and content, the article is divided into two main parts. The first part is a review of the 'traditional' approaches in biblical criticism. It concludes with the definition of some 'gaps' that actually justify the reflection on the need for a contextual approach. The second focuses on the contextualisation of New Testament exegesis. It includes a survey in African biblical studies, a definition of the proposed approach, a definition of one of the methods of this approach and some anticipated 'obstacles' in the application of the new approach as well as an auto-critique of the methodology.

\section{'Traditional' approaches in biblical interpretation and hermeneutical lapses 'Traditional' approaches}

The Bible contains a 'verbal reality' (Chouinard 1997:68) that remains silent unless it is unveiled through scientific research, that is, exegesis. During the Middle Ages, exegesis was aimed at ensuring that biblical interpretation 'squared' with the church's tradition. This conviction, however, has changed gradually over the years. Although exegesis continues to be a discipline that strives for excellence, there has been no unanimity on the nature, the task and especially the way exegesis should be done. The question of methodology is thus being debated at the level of schools of thought, theologians and contexts. This is either due to the tradition in which scholars have been trained or to the many crises affecting various contexts.

In the analysis of texts, biblical scholars have so far concentrated on three aspects of the text: its author, the text itself, and its receptor (Hartin \& Petzer 1991:1). Each proposed methodology

1.In this article, these methods are described as 'traditional' only in contrast to the present work on the contextualisation of New Testament exegesis. 
has thus insisted on either one or two or on all of these poles for a meaningful interpretation. Each of these poles is grounded in a specific 'centre of authority' (Porter 1995:87). For instance, the historical exegetical (diachronic) approach, with the historical context of the text as its centre of authority, focuses on the author of the text. Text-immanent (synchronic) exegesis, on the other hand, has the text itself as its centre of authority and concentrates on the inner structure of the text. And the reader-oriented exegetical approach focuses on the reader or receptor of the text, including contextual issues that surround the reader of the text (e.g. feminism or materialism). A reading of the text that takes the social dynamics embedded in texts seriously nowadays has intently served as a complement to these three traditional approaches. This approach, known as social scientific criticism, renders texts as products of specific social systems (cf. Elliott 1993). In analysing a text, attention is inter alia given to aspects like social institutions, societal arrangements and social values that are part of the social world in which the text originated. This approach goes beyond a mere study of the author and the text in order to understand social structures and social contexts of which the text can be seen as a vehicle. It takes the cultural difference between the first receptors of the text and that of the modern exegete seriously.

Summarily, there has been a positive evolution in the field of biblical criticism. Although such dynamism coincides with the quest for a deeper meaning of biblical texts, it is equally motivated by hermeneutical lapses observed in the various ways in which texts have traditionally been understood and interpreted. In other words, the development of any new exegetical approach has quite often been influenced by the lapses of the former approach(es).

\section{Hermeneutical lapses in the 'traditional' approaches}

The emergence of a contextual approach in the field of biblical interpretation is due to the neglect of the various contexts of application by the 'traditional' exegetical approaches. As a result, societies different from the North American and Western contexts have considered these 'traditional' methods as foreign, since they are either taught in Western and/or American theological institutions or they are taught by exegetes trained from that context. The 'hermeneutical lapses' cited in this article take note of the fact that each of the 'traditional' exegetical approaches has particular shortcomings, which are not discussed here. Rather, it focuses on the lapses that seem common to all these approaches, as compared to a contextual approach. It is therefore the result from the comparison between the 'traditional' exegetical approaches and an approach that focuses on the African context.

From an African point of view, 'traditional' exegetical approaches have seemed abstract because they do not appear to address the African people in their very context. The understanding and use of the term 'abstract' in this article agrees with Dietrich and Luz's (2002) view that:
'Abstract' is not only understood in the usual sense as being opposed to 'concrete'. 'Abstract' also means: unattached to the life and reading of 'ordinary' people, far away from their questions, developed in the ivory tower of the university. 'Abstract' means: detached from the present and from its problems, concerned only with the reconstruction of a past with all its problems. (p. ix)

Secondly, 'traditional' exegetical approaches have been accused for being highly academic (Bevans 1994:12-13; Bray 1996:507) and even more intellectual. Consequently, debates on exegetical approaches have led to the conception of intellectualist methodologies the conclusions of which have so far been believed to have a universal interpretation (Ukpong 2002:17). 'Academic' exegesis thus neglects the grassroots participants as potential contributors to viable theological reflections (cf. Fochang 2006:1). An African contextual approach recognises and validates the fact that theology is not only meant for those who have skills. It is also meant for those who have experiences to share in terms of their faith.

Thirdly, theology in the past has been the exclusive activity of North America and Europe wherein knowledge was displayed in both verbal and written capacities. Today, other contexts contain valuables such as music, storytelling, experiences and other spiritual manifestations such as dancing, which are all necessary in doing theology. As a result of its inception as an academic discipline, exegesis has often been taught in African theological institutions using Western and American contexts as a medium for evaluating other contexts. Hence, other contexts including Africa have been seen as 'inferior' or 'empty', thus ignoring the fact that New Testament texts for example are a combination of several cultural contexts (1st century Mediterranean context; Roman context and even the African context [Ancient Egypt]).

Considering that every interpretation is contextual in a way, interpretations offered by Western and American scholars have been considered as far and remote from other contexts. With this conception, interpretation of biblical texts has often been construed from the standpoint of these scholars, who do not face the same realities that are witnessed by people from the developing world.

Fourthly, 'traditional' approaches have pruned Africans to 'reading' theology rather than 'doing' theology (cf. Green 2009). In view of the current challenges, relevant knowledge is that which leads to creativity and production as opposed to passive participation and a sort of 'spoon-feeding knowledge'. When people are tuned to 'read' theology, they turn to consider texts as foreign, far and remote. When they are engaged in 'doing' theology, they appropriate biblical texts and thus use them to their own advantage.

The above lapses highlight two crucial questions: How can theology be useful to the society? How can those for whom theology is done be implicated in the process? An approach that makes use of the African worldview therefore intervenes as an attempt to make theological findings relevant to the context in which they are practised. This means in other 
words, 'putting theology to work in a practical way in order to manifest the kingdom of God in deeds, not merely in words' (Bray 1996:507). It equally means rendering the communication between the object of theology and its subject viable.

In response to the quest for contextual theology, Bray (1996) has wondered whether:

historically 'oppressed' peoples really have something unique to contribute to academic scholarship, or whether what is happening is that they are progressively being integrated into what has been the European, but is now the global mainstream. (p. 463)

As a relevant contextual approach, an African contextual approach recognises the entire kosmos, including all human beings irrespective of sex, colour and status as the focus of biblical studies. This explains the shift of theological activities from the text and its surrounding context to the context of the audience, which in this article is that of the developing world and the historically marginalised groups.

\section{The contextualisation of New Testament exegesis A survey of African Biblical Studies}

The history of biblical studies in Africa can be traced from the conference in Ibadan, Nigeria of the 'Consultation of African Theologians' in 1966 (Mbiti 1986:73). From then on, interest in African biblical studies has followed about three major trends. Firstly is the Afro-centric hermeneutics, with the emergence of four main exegetical methods: liberation hermeneutics (feminist hermeneutic and deliverance hermeneutic), White South African hermeneutic, missiological hermeneutic and neo-traditional hermeneutic (cf. Krog 2005).

Secondly is the inculturation of biblical hermeneutic, inaugurated by Justin Ukpong in 1996, which has further been enhanced by Loba-Mkole (2008) as intercultural biblical exegesis. It refers to a rereading of texts against the contextual background of the present reader (Loba-Mkole 2008:4).

Thirdly is that which focuses on the context of the audience. It began with 'the comparative method' wherein the reader facilitated the dialogue between the African context and Bible texts for the purpose of appropriation (West 2012:16). ${ }^{2}$ This method as well as that of inculturation actually constitutes the foundation of African biblical studies today.

Many scholars have thus developed a growing interest in the right way of making Scripture relevant to the African context during the last four decades. This effort has culminated in the publication of the Bible in Africa in 2000 and an African Bible Commentary in 2006. Besides, many other scholars have continued to raise several methodological questions that reallocate the exegetical concerns from the author of the text, the text itself, the receptor and the cultural dynamics

2. In this process, the reader must be someone interested in African biblical studies, and not necessarily a 'flesh and blood' African reader. of the text, to the audience for application. Hence, whilst Fashole-Luke (1975:30) worried that Africans contribute quite minimally to the domain of biblical exegesis (cf. Aben 2008:130), Green (2009:xi) simply longed to see theology democratised. ${ }^{3}$ For Schüssler Fiorenza (2009:6), it is the quest to 'marshal arguments for changing graduate biblical education into a radical democratic space of critical inquiry, socio-political ethical exploration, and creative religious re-visioning.' In like manner, Appiah-Kubi (1997), Stinton (2006) and Nyiawung (2010b), have grappled with an African response to the question of Jesus' identity: 'Who do you say I am' (Lk 9:20).

One can therefore conclude that the interest of scholars involved in African biblical studies has been that of contextualisation, characterised by the awareness of the need to relate the results of biblical findings to issues of politics, economy, social justice and the environmental concerns of the African society. This era acknowledges the expiration of the period when Europeans and North American scholars conceived of the Bible providing the text; the Western and North American theologians produced the hermeneutics and the rest of the world only read, consumed and reproduced. In fact, the era approves all contexts as potential grounds for the study, interpretation and application of biblical texts. These developments have thus influenced a reflection on an all-encompassing African exegetical approach, which is both hermeneutic and contextual: the African biblical hermeneutic approach (ABHA).

\section{African biblical hermeneutic approach}

From the survey of African biblical studies, one observes that although there has been a growing interest to read theology focussing on the African worldview, the various efforts have not yet been canalised into a defined exegetical approach. Besides, all the exegetical methods of Afro-centric hermeneutics mentioned above fall under the 'traditional' reader-oriented approach of biblical interpretation (cf. Oeming 2006:v; Van Eck \& Van Aarde 2009:5; Nyiawung 2010b:21) wherein readers initiate contact with the author of the text and thereafter use the results for their own interests' (Oeming (2006:7). Also, African biblical studies have emanated as a result of the lapses of the 'traditional' approaches, seen from an African perspective (as indicated above). Hence, the emergence of an audience-centred approach: the ABHA.

The ABHA therefore focuses on the context of the audience, making use of the results from other methods of exegesis and applying them to the realities of the African context (Nyiawung \& Van Eck 2013:3). It takes its roots from the contexts of biblical writings, before emphasising the relevance of the 'message' to the African people in their context. It is about how issues raised in the Bible can be interpreted and addressed within the social, cultural and religious context of

3.The democratisation of theology according to Green (2009) is in agreement with Rowland and Corner's (1989) view, when they had earlier thought of the liberation Rowland and Corner's (1989) view, when they had earlier thought of the liberation wish to see biblical studies respond to the immediate needs of the context of study. 
Africa. Just as a social scientific reading of New Testament texts is further enhanced by the study of the 1st century Mediterranean world view, an African hermeneutic reading is possible only when the study of the African context is taken seriously (Ukpong 1994:40).

Secondly, the ABHA is a way of rereading, that considers biblical texts as a challenge to African theologians (especially), whose task is to seek solutions to the various problems that plague African societies (Nyiawung 2010a:69). It is an attack, both on African theologians and on the nature of theological training offered in most sub-Saharan African theological institutions. In most cases, the curriculum is still alien to the context of study. The ABHA is therefore an invitation for the retraining and empowerment of African exegetes.

Thirdly, ABHA intends to create a dialogue between the text and the African context through the process of appropriation. It aims at appropriating texts, before interpreting and applying them to the African context. In this process, exegetes encourage the audience to make Scripture part of life, reading it in a way that brings about personal and social transformation. It is only when people start considering Bible stories as real stories that address them in their context that the real process of appropriation begins. West (2009:51) agrees that effective biblical interpretation in Africa must rest on the biblical text, the African context and appropriation. Hence, the ABHA is also about the contextualisation of biblical exegesis, because it seeks to make the existential realities of Africa the subject of interpretation.

Finally, the African context seems to share the same social systems with the context of biblical texts. The ABHA therefore functions on the premise that there exist some African social values, social institutions, societal arrangements and cultural dynamics which are useful in the understanding and interpretation of biblical texts. Hence, there is a need to identify and verify relevant and acceptable African models and theories that can enhance understanding and application. Diachronically, the ABHA proposes to use models and theories in order to better understand, assimilate and interpret biblical texts in the African context. In this way, the exegete escapes from the dual errors of anachronism and ethnocentrism. Synchronically, the ABHA respects the autonomy of texts as vehicles of social communication and of social interaction.

Seen from the above perspective, ABHA encompasses the needs of the inculturation method and other contextual methods. However, it does not claim to be the best approach of biblical interpretation. Rather, it is simply an alternative approach that enriches exegetes (African) in their quest to read and understand what biblical texts actually communicate to their own contexts. One of the contextual methods used in $\mathrm{ABHA}$ is the African biblical interpretation (ABI).

\section{African biblical interpretation Definition}

As discussed, the inculturation of the biblical hermeneutic method stresses the importance of the African context in biblical interpretation. However, when Ukpong and Loba-Mkole speak of 'context' they both refer especially to 'culture'. Africa is a continent with a variety of cultures. Such diversity makes any study in Africa become a huge and complex activity because each African community has its cultural practices, codes and symbols that are only known to them (Hyden 2006:11). Secondly, the method emphasises the context of the reader rather than that of the audience. It is from this background that a method that focuses on the context of the audience has been developed - the African biblical interpretation method.

The ABI is a contextual method of biblical criticism that presents a paradigm shift because of the new demands emanating from the various questions raised by Africans in their quest to appropriate biblical texts. Essentially, it seeks to make a to-and-fro move from: reader - text - context (as in the 'traditional' approaches) to, new context (African) new text (contextualised text) - new reader (African reader). Focus is here placed on the audience, which is the beginning and the end of the exegetical exercise. ${ }^{4}$

In the ABI, therefore, there is a shift from the author and the text to the context (subject of exegesis) and then to the text for the purpose of appropriation. Secondly, there is a move to the original audience in order to share in their experiences. Finally, the text is interpreted and applied in the new context, which is the context of the present day audience. In response to this paradigm shift, Abogunrin (2005:264) has argued that New Testament exegesis was not new in Africa because it had already developed over the years through Origen of Egypt and Augustine of Hippo.

As a complement to West's (2009:51) suggestion that the biblical text, the African context and the act of appropriation are the important elements necessary for an ABI, there is a need to include the contemporary reader, who plays the role of an intermediary between the text, the African context and those who appropriate the text. Biblical texts have meaning only when they are confronted with a given context. The confrontation of a text with a context is the activity of a reader who serves as a facilitator.

Adequate interpretation is possible when exegetes get access to the social systems of the audience for whom the interpretation is intended. This means re-attaching the text and its original context with the context (social location) of the intended audience. An ABI is thus about how to use appropriate and relevant African cultural factors which

4.It is worth mentioning that the audience as the subject of exegesis is here considered 'the beginning and the end' only from the perspective of the conceptual mind of the exegete. Even though the focus of the African biblical interpretation is on the audience, its starting point is the biblical text. 
are related to the realities of the African context in order to understand and interpret texts. The ABI wishes to embrace the variety of the African context in order to tease out possible models that can enhance understanding and thus enable African readers to arrive at a fuller understanding of biblical texts.

In doing theology, there is always the need to reflect on what has been read, on what has been understood and on the context of the application. This final phase is important for the ABI exegetes or readers because it enables them to engage in a dialogue between that which has been read and understood and the context of application. This process grants to exegetes or readers the task of facilitators because of their involvement in enabling the dialogue between the Bible, its context and the African context. This process is that of appropriation. The purpose of every interpretation is for exegetes or readers to place the meaning of a text into specific contexts in such a way that people are able to understand what it means by 'Thus says the Lord' and apply it to make sense in their situation. It is in this way that the ABI is a route to relevant theology, which squarely addresses the needs of the African society.

Tracy (1987:7) and Dietrich and Luz (2002:viii) have rightly observed that interpretation matters in times of cultural crisis. From its history, Africa has been the victim of crises such as misery, poverty, exploitation, the search for individual cultural roots and that of an authentic African Christian faith. The ABI offers the possibility for exegetes to ask new questions to biblical texts in a bid to discover new responses that offer attention to these worries. As an exercise of cross-cultural communication, the ABI is inspired by the use of models and theories from the social sciences. Hence, social-scientific criticism offers a wider spectrum for the understanding of texts from the perspective of the social location of the original reader. The ABI provides a complement by interpreting these texts from the point of view of the social location of the 'new' audience.

\section{What African biblical interpretation is, and is not}

Summarily, an ABI is a pragmatic method that addresses existential problems. Even though the results of exegetical findings are applicable in the context of existential crises, there is a possibility for an extension. As a methodology of its own merit, it does not intend to impose its results on other contexts. However, there is a leeway to adapt these results for use in different contexts. Secondly, it is contextual in its approach and deals with biblical interpretation within a particular context. Thirdly, it is a method that remains open to conversation and criticism.

Fourthly, it establishes a bridge between critical scholarship and life experiences that arise as a result of one's religious convictions. African perceptions are in the greater part emotional and sometimes spontaneous. All these, deriving from personal or community experiences are often subjective as compared to results emanating from critical scholarship. The ABI therefore aims at making a blend between critical exegetical results and empirical experiences that constitute the day to day living of the African context. This also means establishing a relationship between scholarship and faith (Morgan \& Barton 2003:27).

Fifthly, the ABI aims to be critical, but 'faithful' (i.e. with the eyes of faith). Finally, the ABI is a methodology appropriate for the development of an authentic African theology that recognises and addresses the realities of the African context.

In search for a viable foundation for African Christian theology Aben (2008), and Pieterse (2006:122-124) had earlier suggested a 'contextual Bible study' as a possible route. ABI and contextual Bible study all worry about the neglect of the context of the audience in the history of biblical criticism. Both methodologies agree that the ordinary reader is at the centre of creating meaning. They equally agree that biblical study is an interaction between various readers and their respective contextual experiences. Yet, the ABI is not contextual Bible study.

The ABI is not Bible study, which is done within the context of Sunday school (Brown 2000:1). ${ }^{5}$ Whereas Bible study is devotional and gears towards Church knowledge, the ABI overlaps Church doctrine and self-evident truth. Although the $\mathrm{ABI}$ uses results from other traditional methods, it is not social scientific criticism. Whilst social scientific criticism uses models and theories 'there' in order to explain the text as it was understood 'there', the ABI uses models and theories 'here' in order to understand texts that were written 'there'. Equally, the ABI is not reader-response criticism. Whilst reader-response criticism gives credence to the reader, the ABI rather uses the reader as a facilitator in order to understand and address the audience in its context.

Notwithstanding, reader-response criticism, contextual Bible study, Bible study and ABI agree that the ordinary reader (as an active participant) is at the centre of creating meaning. They equally agree that biblical study is an interaction between various readers and their respective contextual experiences. However, the ABI overlaps with these methods because it uses models and theories in order to provide meaning to the text, unlike the contextual Bible study approach for example, which relies mostly on the spontaneous reactions from the readers (Pieterse 2006:124). Reader-response criticism, contextual Bible study and Bible study open room for a variety of readings of a particular text. ABI goes beyond by providing alternative readings and scrutinising the various experiences with the aim of transforming them into knowledge that can be tested and applied in other contexts.

5.The term Sunday school may mean different things to different people, depending on the denomination. For instance, in the Baptist tradition, it is Sunday pre-worship Christian education class which takes place every Sunday before the Sunday worship service. For the Presbyterian Church in Cameroon, it is the 'children Church'. In the service. For the Presbyterian Church in Cameroon, it is the 'children Church'. In the
context of Brown, the term Sunday school is used with reference to neophytes who gather for worship and for Christian nurture (cf. Achu Ngu 2010:10) 


\section{Threats to the understanding and application of African biblical interpretation}

Meanwhile it may not be easy at this stage of the development of an ABI, to enlist all the foreseen and unforeseen threats in its understanding and application, three glaring examples are mentioned below for illustration. They are intended to indicate the complexity involved in the exercise of biblical interpretation within the African context.

\section{High context and low context societies: The diversity in African cultural contexts}

One of the major problems faced by most (if not all) contemporary biblical interpreters is that ancient texts like those in the New and Old Testaments have been described by anthropologists as 'high context' documents ${ }^{6}$ because they are written within the context of the ancient Mediterranean world (Elliott 1993:11; Rohrbaugh 2007:9; Van Eck 2009:13; Nyiawung 2010b:138). Consequently, authors of these texts presume a 'high' knowledge of their context on the part of their readers. As a result, little or no background information is given to these texts in order to explain why certain events occur the way they are described. Rather they leave much to the reader or hearer's imagination and common knowledge (Malina 2001b:2). This is so because authors and original readers of such biblical texts share the same social system and experiences. Of course no biblical author had 21st century readers and their various contexts including the African context in mind.

Now, modern readers, most of whom are from 'low context' societies, need knowledge of the 'missing' information in these texts in order to understand the attitudes of the various characters. Rohrbaugh (1996:2; see also Ps 137:4) describes the eagerness of these readers to understand as well as to 'fill in' the 'missing' information as a situation of someone struggling to 'sing the Lord's song in a strange land'. This is an example of difficulties that one may need to face with the ABI because of the diversity in African cultural contexts.

Africa is a vast continent, with a great diversity in terms of peoples, beliefs and language. Pobee (1992:58) has agreed that Africa is not only a polyracial and a polyethnic continent, but it is also polycultural in terms of its structure. Such a variety also poses a huge problem of appropriation, interpretation and reinterpretation to exegetes involved in African biblical studies.

Considering thefact that hermeneutics involves the translation of meaning from one 'world' to another (Schüssler Fiorenza 2009:73), the ABI targets the African context as the subject of interpretation. Nevertheless, interpreting and applying

6. High context societies are homogeneous societies where contextual knowledge is widely shared by everybody. Changes are rare in such societies. Low context is widely shared by everybody. Changes are rare in such societies. Low context societies, on the contrary, often witness social and technological changes as well as anonymous social relations. For high context societies to be understood, mor background information is required. For Rohrbaugh (2007:9), "[h]igh contex societies expect listeners to know the context and low context societies expect to have to spell it out.' a biblical text from one context to another is an uphill task because it becomes an activity of re-interpretation especially if it is from a different epoch. Such re-interpretation assumes that exegetes are equipped with some kind of basic cultural knowledge from their own resources, which illumine and grant them the various possibilities of completing the text to be interpreted. ${ }^{7}$

In spite of this cultural diversity, African traditional society has some value features like respect and integrity and the concern for moral values that are common to all its societies. It is this conviction that renders the exegetical exercise within the African context possible and practicable. However, the exegete must guard against the dual risk of ethnocentrism and anachronism.

\section{Ethnocentrism and anachronism}

Ethnocentrism is a term that was introduced by Sumner, referring to a'view of things in which one's own group is centre of everything, and others are scaled and rated in reference to it' (Van Eck 1995:9). Said differently, ethnocentrism is an attitude through which values derived from one cultural background are applied to another cultural context, where different values operate (Levine \& Campbell 1972:1). Hence, an in-group culture or attitude is considered as a norm for what is human (Malina 2001c:6), whilst out-group behaviour is seen as a deviation. This judgemental attitude relegates one culture whilst affirming cultural superiority to the other (Strecker 2001:119). Everyone, everywhere at every time, however, does not think and behave identically (Malina 1991:9).

Etymologically, anachronism comes from a combination of two Greek words ana and chronos, meaning an error in chronology in terms of events. The exegete treats a text with the understanding that it is a product of its own social context, although it represents a different time frame. Anachronism then refers to the approach of a text by bringing into it a foreign social world. It is the projection of the patterns and dynamics of the modern world back into the world of antiquity (Rohrbaugh 1991:127). It is an attempt to fashion figures or events of the past to support a 21st century agenda (Malina 2001a:ix).

It is common knowledge that in a society, people have the tendency of projecting their identity whenever the opportunity arises. Also in biblical interpretation just as it is the case with communication, personal identity and cultural orientation are always involved in one way or the other, with exegetes often being tempted to 'fill' the missing gap in the text with information with which they can easily identify. Quite often such information either reflects their world view

7.In the case of re-interpretation, exegetes need basic cultural knowledge (cultural self-awareness) from about three sources. They need cultural knowledge from the social context of the text; from the social location of the audience and knowledge from their own context of origin else they run the risk of ethnocentrism. A blend of knowledge from these varied sources offers exegetes a wide range of reinterpretation opportunities. Rohrbaugh (2007:xi) refers to such activity of reading and completing meaning from one context to another by a modern reader as 'recontextualization', because it involves the process of moving language and altering meaning. 
or it reflects the identity of the group to which they belong. Rohrbaugh (2007:7) opines that such an attitude could lead readers to reject the other, or they project stereotypes onto the other or they simply project the characteristics of their own identity which is considered as a norm. This attitude erroneously gives such readers the impression that their context is of superior value.

This was probably the error of early missionaries to Africa, who began the process of evangelisation by considering the African context as a context void of elements that could enhance the understanding and interpretation of Scripture. According to Ehioghae (2005:308), 'missionaries did indeed transplant their European culture along with their efforts to Christianise the African continent.' Aben (2008:10) agrees that missionaries 'imposed their austere socio-political, culture and religious beliefs on Africans and forced Africans to take on European cultural habits.' Hence, evangelisation was rather conceived from a paternalistic perspective, thereby giving birth to ethnocentrism, whose end product was prejudice, misjudgement and hostility (cf. Korostelina 2007:139).

As a remedy to the above situation, several African scholars have insisted on a search for an authentic African theology which consists of seeking for similarities between the present day context and the context of the Bible (cf. Aben 2008), an attitude of anachronism. Rorhbaugh (1996:2) concurs that the process of understanding another culture is never an easy one. Consequently, modern exegetes must be careful when biblical stories seem familiar and comfortable because the Bible was not written specifically for African readers of the 21st century.

The activity of biblical interpretation necessitates a lot of creativity. However, to fall into the trap of ethnocentrism and/or anachronism is a wrong theological creativity, which is eisegesis, because in that way the exegete simply sticks his own words into the mouth of the biblical writer (Malina 1991:23).

\section{A solution? Cross-cultural reading}

Besides the threats cited above, there exist other subtle threats such as the inability of African theologians to agree on a common methodology in the reconstruction of 'African theology'. In this light, Aben (2008:104) criticises early African theologians like Harry Sawyer, J.K. Agbeti and John Mbiti, describing their theological method as 'syncretism'. There is also the question of the a-historical nature of African traditional religion, which albeit remains an important source of information for the recollection of models and theories from the African context that are appropriate for an ABI.

The above threats are not to be feared, instead, they should be considered as a guard to contemporary readers interested in ABI. There are 'safety measures' that are intended to create awareness in the difficulties that one encounters when interpreting a text from one cultural context to another. Although these are legitimate threats, they are not a hindrance as such; they can be surmounted and managed.

As a solution, Rohrbaugh (1996:1) has proposed a crosscultural reading of the biblical texts as an indispensable route which can then offer an $\mathrm{ABI}$ a great potential for an effective reading, understanding and interpretation. A cross-cultural reading enables readers to understand biblical characters in their own terms before interpreting their behaviour to another context.

In agreement with Rohrbaugh, Rhoads (1992:136) has described 1st century texts (of the New Testament) as a 'keyhole, an opening through which to look into another culture, in a different world.' Reading the Bible crossculturally implies a sound knowledge of insights from cultural anthropology because the various biblical texts are those that concern the lives and the behaviour of people within a specific sociocultural, political and religious setting.

Contemporary readers engaged in the activity of biblical (re-)interpretation, must guard against ethnocentrism, whether they are part of the context of application or not. The following guidelines are an important guide for an effective use of an ABI, namely, (1) knowledge of the social systems of biblical texts; (2) the use of models and theories in social scientific criticism in order to explicate the social systems of texts; (3) the understanding and application of social scientific criticism as an approach that enhances the practice of African biblical interpretation; and (4) the use of appropriate models and theories from the African context for the purpose of reinterpretation. The above guidelines will enable the exegete to check - in an abductive way ${ }^{8}$ - presuppositions as well as the results of interpretation (Van Eck 1995:223).

\section{Critique of the approach}

The ABHA has emerged from asking questions concerning the subject of exegesis; questions that have been framed on the basis of the context of the audience for whom the study is effected. Biblical texts being a sort of 'verbal construct where words make worlds, where words lead us and tease us and plunge us into multiple possibilities of meaning' (Gunn 1999:225), the ABHA does not do everything that can be done and ought to be done in African biblical studies. However it offers a possibility of interpreting texts so as to make the Bible relevant for African Christianity and serves as a complement to the other 'traditional' approaches.

In the eyes of its critics, the ABHA may seem inappropriate because of some of the threats already cited above. As discussed earlier, the diversity of the African cultural

8.The abductive method of research is an alternative to the traditional inductive and hypothetico-deductive accounts of scientific methods of investigation. In the inductive method the researcher observes facts from which generalised conclusions inductive method the rears about particular issues are made (see Chalmers 1999). In the hypothetico-deductive method the researcher suggests a hypothesis which is then tested. From this process, some other observational predictions can then also be derived. The abductive method is broader; it evolves from the construction of empirical facts to the construction of theories, which in turn explain these facts. It is a metho of investigative theory that enables the exegete to move, for example, from the 'facts' to the detection of empirical phenomena that are found in the social world of a given text. 
contexts is a possible hindrance to the development and application of an exegetical hermeneutic approach from the African context. Yet there exist religious, social, economic and political problems that are unique to all societies of the African continent. It is in this sense that an exegetical approach that addresses God's response to these crises is legitimate.

One equally presumes to see the ABHA under attack because of the risk of syncretism. This would be a misjudgement (especially if it came from someone who does not share in the same social location with a particular context of the African society). The ABHA's point of departure is not the African context but the biblical text, which is read with focus on the social location of the African context. Likewise, the ABHA is not about a blind fusion of Christianity with elements of African traditional religion (Aben 2008:100), which implies using African traditional religion to produce Christianity. Rather, the ABHA depends on the use of appropriate models and theories from the African context.

Finally, as a contextual approach, the ABHA focuses on the realities of a particular context, some of which can only be defined from personal experiences. In other words, the ABHA is done only from a specific perspective and as such does not necessarily address issues from a universal standpoint. This methodology thus poses the serious problem of objectivity, which is rather peculiar to all exegetical approaches (Gunn 1999:226).

In spite of the above criticisms, exegesis remains a lovely activity. Although the gospel message remains the same, its understanding and interpretation evolve and vary according to time and place. Hence, the ABHA enables the exegete to pose new questions that provide new solutions, depending on the environment. It renders the cross-cultural reading of the Bible lively, making the gospel not to sound foreign; even if it came as a new idea (Skreslet 2006:119).

An African hermeneutic approach in biblical criticism facilitates the African understanding of the Bible as containing God's Word, addressed to all humanity. The application of biblical truths to the realities of the African context equally enables Africans to accept that God's plan for salvation includes the African continent with its problems. It thus brings hope to a continent whose peoples have lived in misery and expectation. This approach offers a clue as to how Jesus is also involved in the process of transformation; transforming the meaning of Africa as a 'dark continent' to a new Africa which has become an important and unavoidable source for theological reflection in the world.

\section{Conclusion}

From its description it is clear that the ABHA creates awareness of the fact that all contexts are potentials for the reading and application of biblical texts. It equally creates awareness of the cross-cultural similarities between the context of the Bible and that of Africa. In fact, the situation of misery in the African continent necessitates a shift of emphasis in biblical criticism. Emphasis can no longer be placed on the text's meaning or be derived from the context of the text alone. Rather, there is also a need to focus on the meaning that the text has for the people who are actually the beneficiaries of the exegetical exercise.

To sum up, the ABHA is a better option for a viable African contextual theology. Different approaches in biblical criticism have different and particular functions and address particular issues, depending on the type of text that has been chosen (Porter \& Tombs 1995:13; Van Eck \& Van Aarde 2009:47). The ABHA does not make an exception. The responses that the exegetes arrive at are dependent on the questions asked. It is this exercise that makes of exegesis a dynamic activity.

\section{Acknowledgements Competing interests}

The author declares that he has no financial or personal relationship(s) that may have inappropriately influenced him in writing this article.

\section{References}

Aben, T.A., 2008, African Christian Theology: Illusion \& reality, Africa Christian Textbooks, Bukuru. PMid:16235768, PMCid:PMC2475384

Abogunrin, S.O., 2005, Decolonization of biblical interpretation in Africa, Nigerian Association for Biblical Studies, Ibadan. PMid:16235768, PMCid:PMC2475384

Achu Ngu, 2012, 'The formation of Sunday School Teachers (SUST) of the PCC as a fulfilment of 2 Timothy 2:1-2', BTh thesis, Department of Practical Theology, Presbyterian Theological Seminary Kumba.

Appiah-Kubi, K., 1997, 'Christology', in J. Parratt (ed.), A reader in African theology, new edn., pp. 65-74, Society for Promoting Christian Knowledge, London.

Bediako, K., 2000, Jesus in Africa: The Christian gospel in African history and experience, Editions Clé, Yaounde.

Bevans, S.B., 1994, Models of contextual theology, Orbis Books, Maryknoll. PMid:7834441

Bray, G., 1996, Biblical interpretation: Past and present, InterVarsity Press, Downers Grove.

Brown, M.J., 2000, What they don't tell you: A survivor's guide to Biblical Studies, Westminster John Knox Press, Louisville.

Chalmers, A.F., 1999, What is the thing called science?, 3rd edn., University of Queensland Press, St. Lucia.

Chouinard, L., 1997, 'Gospel Christology: A study of methodology', in S.E. Porter \& G.A. Evans (eds.), The New Testament interpretation and methods: A Sheffield reader, pp. 65-81, Sheffield Academic Press, Sheffield.

Dietrich, W. \& Luz, U. (eds.), 2002, The Bible in a world context: An experiment in contextual hermeneutics, William B. Eerdmans Publishing Company, Grand Rapids.

Ehioghae, E.M., 2005, 'Decolonizing Jesus in Africa: A critical evaluation of the missionary influence', in S.O. Abogunrin (ed.), Decolonization of biblical interpretation in Africa, pp. 307-321, Nigerian Association for Biblical Studies, Ibadan.

Elliott, J.H., 1993, What is social scientific criticism?, Fortress Press, Minneapolis.

Fashole-Luke, E.W., 1975, 'The quest for African Christian theology', The Journal of Religious Thought 32, 80.

Fochang, B., 2006, Keep your daily appointment with God: Story-like meditations for daily spiritual nourishment, vol. 2, Missionaries Memorial Research Centre Publications, Bali, Bamenda.

Green, L., 2009, Let's do theology: Resources for contextual theology, Mowbray, London.

Gunn, D.M., 1999, 'Narrative criticism', in S.L. McKenzie \& S.R. Haynes (eds.), To each its own meaning: An introduction to biblical criticisms and their application, pp. 201-229, Westminster John Knox Press, Louisville.

Hartin, P.J. \& Petzer, J.H., 1991, 'Introduction', in P.J. Hartin \& J.H. Petzer (eds.), Text and interpretation: New approaches in the criticism of the New Testament, pp. 1-11, Brill, Leiden.

Hyden, G., 2006, African politics in comparative perspective, Cambridge, University Press.

Korostelina, K.V., 2007, Social identity and conflict: Structures, dynamics, and implications, Palgrave Macmillan, New York. http://dx.doi.org/10.1057/9780230605671 
Krog, L., 2005, African hermeneutics: The current state, Master's thesis, Department of Biblical Studies, South African Theological Seminary.

Levine, R.A. \& Campbell, D., 1972, Ethnocentrism: Theories of conflict, ethnic attitudes and behaviour, John Wiley \& Sons, Inc., New York.

Loba-Mkole, J-C., 2008, 'Rise of intercultural biblical exegesis in Africa', HTS Teologiese Studies/Theological Studies 64(3), 1347-1345. http://dx.doi.org/10.4102/hts. v64i3.77

Malina, B.J., 1991, 'Reading theory perspective: Reading Luke-Acts', in J.H. Neyrey (ed.), The social world of Luke-Acts: Models for interpretation, pp. 3-23, Hendrickson Publishers, Peabody.

Malina, B.J., 2001a, 'Dedication', in W. Stegemann, B.J. Malina \& G. Theissen (eds.) The social setting of Jesus and the Gospels, pp. vii-ix, Fortress Press, Minneapolis. PMCid:PMC34606

Malina, B.J., 2001b, The social Gospel of Jesus: The kingdom of God in Mediterranean perspective, Fortress Press, Minneapolis. PMCid:PMC34606

Malina, B.J., 2001c, 'Social-scientific methods in historical Jesus research', in W. Stegemann, B.J. Malina \& G. Theissen (eds.), The social setting of Jesus and the Gospels, pp. 3-6, Fortress Press, Minneapolis.

Mbiti, J.S., 1986, Bible and theology in African Christianity, Oxford University Press, Oxford.

Morgan, R. \& Barton, J. (eds.), 2003, Biblical interpretation, Oxford University Press, Oxford.

Nyiawung, M.D., 2010a, 'The prophetic witness of the church as an appropriate mode of public discourse in African societies', HTS Teologiese Studies/Theological Studies 66(1), Art. \#791, 8 pages. http://dx.doi.org/10.4102/hts.v66i1.791

Nyiawung, M.D., 2010b, 'Who is the Christ? Leadership and conflict in Luke 9:18-22: A social scientific- and narratological analysis from an African perspective', PhD thesis, Department of New Testament Studies, University of Pretoria.

Nyiawung, M.D. \& Van Eck, E., 2013, 'An African hermeneutic reading of Luke 9:1822 in relation to conflict and leadership in pastoral ministry: The Cameroonian context', HTS Teologiese Studies/Theological Studies 69(1), Art. \#1201, 9 pages, http://dx.doi.org/10.4102/hts.v69i1.1201

Oeming, M., 2006, Contemporary biblical hermeneutics: An introduction, Ashgate Publishing Limited, Aldershot.

Pieterse, W., 2006, Truth and story: Reading biblical narrative, Presprint PIc, Limbe

Pobee, J.S., 1992, Skenosis: Christian faith in an African context, Mambo Press, Gweru. PMid:1484947

Porter, S.E., 1995, 'Literary approaches to the New Testament: From formalism to deconstruction and back', in S.E. Porter \& D. Tombs (eds.), Approaches to New Testament study, pp. 77-128, Sheffield Academic Press, Sheffield.

Porter, S.E. \& Tombs, D., 1995, 'Introduction', in S.E. Porter \& D. Tombs (eds.), Approaches to New Testament study, pp. 13-16, Sheffield Academic Press, Sheffield. PMid:7475254
Rhoads, D., 1992, 'Social criticism: Crossing boundaries', in J.C Anderson \& S.D. Moore (eds.), Mark and methods: New approaches in Biblical studies, pp. 135-161, Fortress Press, Minneapolis.

Rohrbaugh, R.L., 1991, 'The pre-industrial city in Luke-Acts: Urban social relations', in J.H. Neyrey (ed.), The social world of Luke-Acts: Models for interpretation, pp. 125-149, Hendrickson Publishers, Peabody.

Rohrbaugh, R.L., 1996, 'Introduction', in R.L. Rohrbaugh (ed.), The social scientific and New Testament interpretation, pp. 1-15, Hendrickson Publishers, Peabody.

Rohrbaugh, R.L., 2007, The New Testament in cross-cultural perspective, Cascade Books, Eugene.

Rowland, C. \& Corner, M., 1989, Liberating exegesis: The challenge of liberation theology to biblical studies, Westminster John Knox Press, Louisville.

Schüssler Fiorenza, E., 2009, Democratizing biblical studies: Toward an emancipatory educational space, Westminster John Knox Press, Louisville.

Skreslet, S.H., 2006, Picturing Christian witness: New Testament images of disciples in mission, William B. Eerdmans Publishing Company, Grand Rapids.

Stinton, D.B., 2006, Jesus of Africa: Voices of contemporary African Christology, Orbis Books, Maryknoll.

Strecker, C., 2001, 'Jesus and the demoniac', in W. Stegemann, B.J. Malina \& G. Theissen (eds.), The social setting of Jesus and the gospels, pp. 117-133, Fortress Press, Minneapolis.

Tracy, D., 1987, Plurality and ambiguity, religion, hope, Harpers \& Row, San Francisco. PMCid:PMC1477713

Ukpong, J.S., 1994, 'Christology and inculturation: A New Testament perspective', in R. Gibellini (ed.), Paths of African Theology, pp. 40-61, Orbis Books, Maryknoll.

Ukpong, J.S., 1996, The parable of the shrewd manager (LK 16:1-13): An essay in the intercultural Biblical hermeneutic', Semeia 73, 189-210.

Ukpong, J.S., 2002, 'Inculturation hermeneutics: An African approach to biblical interpretation', in W. Dietrich \& U. Luz (eds.), The Bible in a world context, pp. 17-32, William B. Eerdmans Publishing Company, Grand Rapids.

Van Eck, E., 1995, Galilee and Jerusalem in Mark's story of Jesus: A narratological and scientific reading, Kital, Pretoria. (HTS Teologiese Studies/Theological Studies suppl. 7).

Van Eck, E., 2009, 'Interpreting the parables of the Galilean Jesus: A social-scientific approach, HTS Teologiese Studies/Theological Studies 65(1), Art. \#308, 12 pages. http://dx.doi.org/10.4102/hts.v65i1.308

Van Eck, E. \& Van Aarde, A.G., 2009, 'Encyclopaedia of the New Testament', class notes, ONM 152, BYA 120, OUN 142, University of Pretoria, Pretoria.

West, G.O., 2009, 'Interpreting the Cooperative Paradigm in African biblical scholarship', in H. de Wit \& G.O. West (eds.), African and European readers of the Bible: In quest of a shared meaning, pp. 37-64, Cluster Publications, Pietermaritzburg. PMid:18648075

West, G.O., 2012, 'After the missionaries: Historical and hermeneutical dimensions of African appropriations of the Bible in Sub-Saharan Africa', Studia Historiae Ecclesiasticae 38(1), 111-130. 